\title{
The hydrogeology of the Uitenhage Artesian Basin with reference to the Table Mountain Group Aquifer
}

\author{
LGA Maclear \\ SRK Consulting Engineers and Scientists, PO Box 21842, Port Elizabeth 6000, South Africa
}

\begin{abstract}
The Uitenhage Artesian Basin (UAB) lies in the Eastern Cape and is South Africa's most important artesian groundwater basin, supplying approximately $1400 \mathrm{M} / \mathrm{yr}(44 \ell / \mathrm{s})$ of water from springs for domestic use to Uitenhage, as well as supporting large citrus irrigation schemes. Groundwater from this basin has been extensively utilised from the early part of the $20^{\text {th }}$ century, including periods of over-exploitation resulting in the declaration of a groundwater control area to limit abstraction to sustainable rates.

The aquifer comprises fractured Table Mountain Group (TMG) sandstones confined in the eastern part of the basin by overlying Cretaceous siltstones and mudstones, resulting in artesian conditions. The Coega Fault is a major structural feature dividing the basin into separate systems, viz. the southern Swartkops Aquifer and the northern Coega Ridge Aquifer, that are hydrogeologically independent of each other. The Elands River syncline divides the Swartkops Aquifer further into the Kruisrivier and Bethelsdorp Units.

Borehole yields commonly range from 5 to $10 \ell / s$ and the groundwater quality is excellent with low salinities. Water hardening, however, is required due to the acidic and corrosive nature of the groundwater, typical of other Table Mountain Group aquifers in South Africa. Using ${ }^{14} \mathrm{C}$ data, the age of the groundwater in the basin ranges from 1500 to 28000 years with a calculated flow rate of $0.8 \mathrm{~m} / \mathrm{a}$. From the chloride mass balance method, recharge rates are determined to be 25 to $55 \%$ of annual rainfall. Groundwater temperatures generally show that depths of groundwater strikes do not necessarily correspond with depth of origin, indicating a complex groundwater circulation pattern within the basin.

Whilst the UAB has been well studied locally, a basin-scale hydrogeological characterisation is considered to be necessary, followed by recommendations and formulation of a management plan to ensure the continued sustainability of groundwater supply from this national asset.
\end{abstract}

\section{Introduction}

The UAB is South Africa's largest and hydrogeologically most important artesian groundwater basin, supplying surface-water and groundwater for agricultural, domestic, commercial and industrial uses. It covers an area of about $3700 \mathrm{~km}^{2}$, occurring mostly within the Port Elizabeth and Uitenhage Districts in the Eastern Cape, and is recharged by rainfall on the Groot Winterhoek and Zunga mountain ranges to the west. Groundwater from this basin currently supplies approximately $15 \%$ of the total municipal requirements of Uitenhage, one of the Eastern Cape's largest industrial areas, indicating the strategic importance of this basin. However, by the same token, the urbanised nature of the central and eastern portions of the $\mathrm{UAB}$ has resulted in pressure on this vulnerable water resource. Increasing demand on the resource has resulted in an increase in the potential for over-exploitation and contamination.

Hydrogeological conditions along the Coega Ridge and in the Kruisrivier region in the basin changed after 1908 from a freeflowing artesian system to a sub-artesian system. This was due to the arrival of drilling machines in the area and the resultant rapid increase in the number of boreholes drilled to augment the yield from the artesian basin for irrigation. In 1950 the Hall Commission heard evidence regarding the weakening flow conditions in the $\mathrm{UAB}$. As a result of substantial pressure from farmers in the region, the basin was declared a Subterranean Government Water Control

푱(041) 581-1911; fax: (041) 581-1964; e-mail: gmaclear@srk.co.za Received 3 October 2000; accepted in revised form 12 July 2001.
Area (SGWCA) in 1957. The Uitenhage SGWCA that encloses the central and eastern portion of the UAB is shown in Fig. 1 and covers an area of $1125 \mathrm{~km}^{2}$.

Since the declaration of a control area, the UAB has been extensively researched with various groundwater studies having been conducted during the latter half of the $20^{\text {th }}$ century. These studies were commissioned primarily to characterise the hydrogeology of the basin and to determine the effect of various influences affecting the flow conditions within the aquifer. This paper is a synthesis of the characteristics of the UAB with reference to the hydrogeology of the TMG.

\section{Physiography}

The western part of the basin is dominated by high west-northwest striking mountain ranges (viz. the Groot Winterhoek, the Elands and the Zunga Berge) comprising the main catchment area and the lower-lying Van Stadens Berg to the south. Towards the east, the mountain ranges are fringed by low-lying terraced coastal plains that dip gently seawards and surround an extensive alluvial floodplain and estuary. Isolated koppies - formed by inliers of TMG sandstone - project through the soft Cretaceous strata in the coastal area and along Coega Ridge.

The basin enjoys a moderate mean annual precipitation of $636 \mathrm{~mm}$ with rain during all seasons, mostly due to orographic influences. The rainfall is, however, variable over the whole basin with the highest falls in the mountainous catchment $(760 \mathrm{~mm} / \mathrm{a})$ decreasing to $435 \mathrm{~mm} / \mathrm{a}$ at Uitenhage. The region has a temperate climate with warm summers and mild winters and annual evaporation in the region of $1650 \mathrm{~mm}$. 

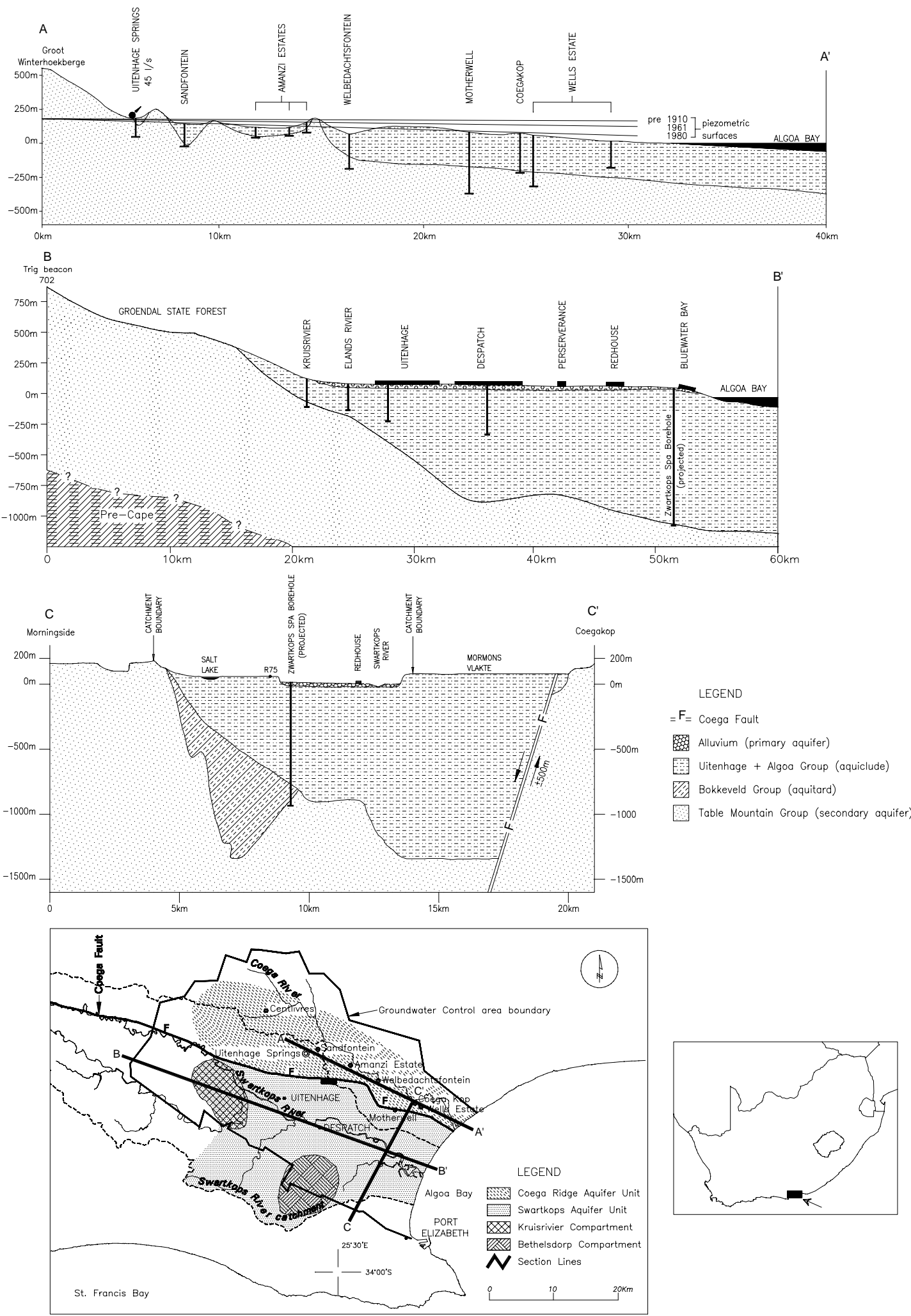

Figure 1

Aquifer delineation and hydrogeology of the Uitenhage Artesian Basin (from Maclear, 1996) 
The easterly flowing Swartkops River and its two main tributaries, viz. the Kwa-Zunga and Elands Rivers, are the major perennial drainage features of the basin with minor ephemeral rivers draining the southern catchment area. The predominant drainage features follow structural weaknesses in the west of the basin grading to an open-valley floodplain and estuary in the east.

\section{Geology}

The geologically dominant feature in the study area is the WNWESE striking and plunging depositional trough delineated by Van Eeden (1952). The present-day UAB was an open basin in the Jurassic period (120 million years ago), ringed by mountains to the north, south and west (Mountain, 1955). Pebble and boulder alluvial deposits were washed from these mountains under a highenergy environment of deposition and accumulated mainly along the western margin of the basin to form the Enon Formation conglomerate and sandstone. Clays were then deposited unconformably on the Enon Formation - under a basin-entry depositional environment to form the mudstones and siltstones of the Kirkwood Formation. Subsequent invasion of the basin by the sea deposited marine to estuarine clays to form the Sundays River Formation.

During the Tertiary Period, numerous periods of marine transgression formed terraces in the Cretaceous sediments of the $\mathrm{UAB}$ and deposited a veneer of calcareous sandstones (Algoa Group) with sea-level retreat.

The west and southern portion of the basin - comprising the Groot Winterhoekberge, the Kwa-Zunga River valley and the Elands and Van Stadens Berge - is formed by quartzitic TMG sandstones. Bokkeveld Group shales underlie a large part of the Elands River catchment, in the central west of the basin. The central portion of the basin consists mainly of Uitenhage Group deposits with river alluvium in the valley and floodplain areas. Quaternary floodplain and Cretaceous terrace deposits of the Algoa and Uitenhage Groups comprise the eastern part of the basin, with mudstones and sandstones of the Kirkwood Formation forming the rolling hills southeast of Uitenhage.

\section{Structure}

Post-Cape lateral compression during the Cape Fold Belt orogeny produced zones of intense folding that produced the dominant, regional east-southeast trending folds in the Cape Supergroup rocks, forming the mountain chains in the UAB. Two large ESEstriking regional folds form the Elands River Syncline in the south and the Swartkops River Anticline in the north (Toerien and Hill, 1989). Figure 1 shows simplified geological profiles through the study area and illustrates the geometry of the aquifer units.

The Coega Fault is the major structural feature in the region and is the eastern extension of the regional scale Coega-Baviaanskloof Fault Zone (Hill, 1988). The Coega Fault is traceable from west of Groendal Dam eastward to the coast and is a normal tensional fault with an average vertical southward displacement of the Cretaceous sediments of $550 \mathrm{~m}$ (Marais and Saayman, 1965).

The downthrow on the fault is hydrogeologically significant since:

- It makes aquifer penetration logistically and economically not feasible for small-scale drill rigs on the southern side of the fault in the central regions of the study area.

- The aquiclude overlying the Swartkops Aquifer is juxtaposed against the artesian Coega Ridge Aquifer (See below for aquifer delineation detail).

\section{Hydrogeology}

The UAB is a complex, fractured rock aquifer with the basin configuration controlled by post-depositional faulting in the north and folding in the south. The UAB's natural boundaries are the Indian Ocean to the east, the TMG-Bokkeveld Group contact in the vicinity of the Coega River to the north, the Groot Winterhoekberge to the west and the St. Albans Flats (west of Port Elizabeth) to the south. The potential sustainable yield of the UAB aquifer was estimated at $80 \ell / \mathrm{s}$ by Venables (1985), with individual borehole yields generally greater than $5 \ell / s$.

The UAB is subdivided hydrogeologically by the Coega Fault into two major aquifer systems, viz. the relatively shallow Coega Ridge Aquifer (CRA) north of the Coega Fault and the deeper Swartkops Aquifer (SA) to the south of the fault (Fig. 2). The two aquifer systems function independently from one another, i.e. abstraction from a borehole in one unit only affects the yield of boreholes or springs in that unit, and not in the neighbouring unit.

The Swartkops Aquifer is further subdivided into the Kruisrivier Unit and Bethelsdorp Unit by the low permeability to impermeable Bokkeveld Group infill of the Elands River Syncline and the Swartkops River Alluvial Aquifer that occurs as a thin narrow unit over most of the Swartkops Aquifer. The characteristics of the aquifers within the Uitenhage Artesian basin are summarised in Table 1.

\begin{tabular}{|c|c|c|c|c|c|c|c|}
\hline \multicolumn{8}{|c|}{$\begin{array}{c}\text { TABLE } 1 \\
\text { Hydrogeology of the aquifer units within the Uitenhage Artesian Basin }\end{array}$} \\
\hline Aquifer & $\underset{\mathbf{m}^{2} / \mathbf{d}}{\mathbf{T}}$ & s & $\begin{array}{l}\mathbf{Q} \\
\ell / \mathbf{s}\end{array}$ & $\begin{array}{l}\mathrm{TDS} \text { * } \\
\mathrm{mg} / \ell\end{array}$ & $\begin{array}{l}\text { Water temp. } \\
\quad \text { oC }\end{array}$ & $\begin{array}{c}\text { Abstraction } \\
\mathrm{Mm}^{3} / \mathrm{a}\end{array}$ & $\begin{array}{l}\text { Size } \\
\mathbf{k m}^{2}\end{array}$ \\
\hline Coega Ridge: & $50-400$ & $2 \times 10^{-4}$ & $3-23$ & 170 av. & $23-33$ & 4.7 & 470 \\
\hline $\begin{array}{l}\text { Swartkops: } \\
\text { Kruisrivier unit }\end{array}$ & $2-90$ & $5 \times 10^{-2}$ & $0.4-16$ & $\begin{array}{c}- \\
200-8800\end{array}$ & $\begin{array}{c}18-55 \\
-\end{array}$ & $\begin{array}{c}- \\
3.3(1995)\end{array}$ & $\begin{array}{c}- \\
110\end{array}$ \\
\hline Bethelsdorp unit & - & - & $1-4$ & $500-30000$ & - & $\begin{array}{c}1.7(1993) \\
0.8(1961) \\
0.01(1993)\end{array}$ & 150 \\
\hline $\begin{array}{l}\text { * TDS is variable } \mathrm{c} \\
\text { the Uitenhage G }\end{array}$ & ding on & ogy & Irce $r$ & low salini & the TMG and & oderate to hig & linity ir \\
\hline
\end{tabular}




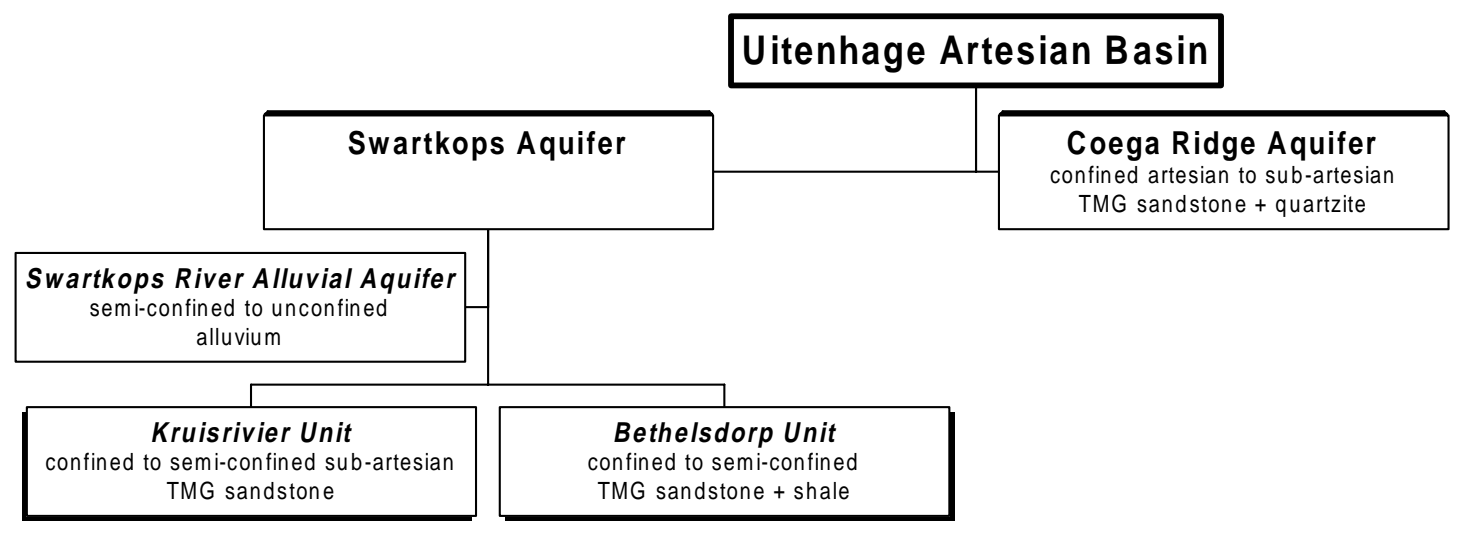

Figure 2

Subdivision of the Uitenhage Artesian Basin

\section{Aquifer types}

Two aquifer types occur in the UAB, viz. the minor, shallow semiconfined to unconfined, primary Swartkops River Alluvial Aquifer; and the deeper major artesian to sub-artesian, fractured secondary aquifer, in quartzites of the TMG, and basal sandstone and conglomerate layers of the Enon Formation. Most of the artesian groundwater within the secondary aquifer is restricted to relatively narrow, well-defined zones of intense fracturing.

The alluvial aquifer is separated vertically from the fractured TMG aquifer in the central to eastern parts by confining layers of Uitenhage Group sediments (primarily Kirkwood Formation mudstones), which form an aquiclude and result in artesian conditions in the TMG Aquifer. The Elands River Syncline striking east towards Port Elizabeth, exposes the Bokkeveld shales (aquitard) below the Cretaceous rocks. The syncline is hydrogeologically significant in the study area where the shales form an impermeable barrier, dividing the SA into the southern Bethelsdorp and the northern Kruisrivier units (Marais, 1965). The majority of abstraction in the SA occurs in the Kruisrivier Unit, where groundwater is pumped for irrigation purposes.

To the south and west, the secondary TMG Aquifer is separated horizontally by low-permeable sediments of the Bokkeveld Group (Fig. 1). The Coega Fault marks the boundary in the UAB between artesian conditions in the SA in the southern downthrown side, and the CRA in the northern upthrown side.

\section{Groundwater quality}

Groundwater in the TMG fractured aquifer is of an excellent quality with salinities generally less than $15 \mathrm{mS} / \mathrm{m}$ and is fit for drinking in its raw state. Due to its low fluoride content, however, addition of fluoride, and/or blending of groundwater with surface water is needed if it is to be used as a sole long-term drinking supply. In addition, water hardening is required due to low $\mathrm{pH}$ as is the case at the Uitenhage Springs.

\section{Groundwater flow rates and recharge}

All groundwater samples analysed from the confined zones of the CRA, have zero Tritium (Venables, 1985), indicating that the water being pumped from the sampling boreholes is older than 55 years and that no recent recharge is occurring at the sampling sites. No intensive study on aquifer recharge has been undertaken for the basin. Utilising the chloride mass balance method, Maclear (1996), determined recharge to the TMG Aquifer feeding the Uitenhage Springs to range from 25 to $55 \%$ of annual rainfall.

In a study by Talma et al (1982), a recognisable trend of increasing ages of groundwater with increasing distance eastward along the strike of the Coega Ridge was identified from ${ }^{14} \mathrm{C}$ data. The age of the groundwater ranges from 1500 years at the Uitenhage Springs immediately east of the recharge area, to 28000 years at the Coega Kop discharge area (Heaton et al., 1986). From these dates, the flow rate along the flow-path in the CRA is calculated at $0.8 \mathrm{~m} / \mathrm{a}$.

\section{Groundwater temperature}

The available groundwater temperature data from boreholes drilled into the TMG Aquifer in the UAB show little correlation between groundwater temperature and borehole depth, to be expected in a confined aquifer system. The groundwater temperature is a function of the depth of circulation of the groundwater system rather than the depth of the water-strike in a borehole.

From the temperature, the circulation depth of the groundwater in the aquifer can be determined, although the differing thicknesses of the overlying Cretaceous sediments in different portions of the basin makes interpretation difficult with respect to applying a simple geothermal gradient to the TMG. For example, the $160 \mathrm{~m}$ deep borehole drilled into Eye 2 at the Uitenhage Springs was drilled directly into the $\mathrm{TMG}$ and has a groundwater temperature of $23^{\circ} \mathrm{C}$, whereas the Amanzi Estate borehole is only $55 \mathrm{~m}$ deep, has a Cretaceous overburden of $38 \mathrm{~m}$, and a temperature of $33^{\circ} \mathrm{C}$. Using a geothermal gradient of $37 \mathrm{~m} /{ }^{\circ} \mathrm{C}$ (from Jones, 1992) and an ambient temperature for the recharge water of $18^{\circ} \mathrm{C}$, the temperature of Eye 2 at Uitenhage Springs indicates a groundwater circulation depth of $185 \mathrm{~m}$ compared with $555 \mathrm{~m}$ for the Amanzi Estates borehole. In contrast, the circulation depth of the $54^{\circ} \mathrm{C}$ artesian groundwater that flowed out of the old Zwartkops Spa borehole (discussed in a following section) is estimated at $1330 \mathrm{~m}$.

\section{Coega Ridge Aquifer}

The CRA occurs in the north-central portion of the study area. This aquifer is comprised of quartz arenites of the TMG overlain by impermeable mudstones and siltstones of the Uitenhage Group, which forms an aquiclude. The aquifer stretches from immediately west of the Uitenhage Springs, eastward along Coega Ridge, to the 
coast. The steep $\left(50^{\circ}\right)$ northerly dipping TMG-Bokkeveld Group contact to the north forms the northern boundary to this aquifer.

The CRA is economically significant as the source of the artesian to sub-artesian groundwater at points of large-scale abstraction, viz. Uitenhage, Sandfontein, Amanzi Estates, Coega Kop and Wells Estate (Figs. 1 and 3), where groundwater is used for irrigation of citrus (for export) and lucerne, as well as for domestic use.

A strong degree of hydraulic connectivity exists between the boreholes along the Coega Ridge, discussed in detail by Maclear and Woodford (1995). The nature of this relationship is, however, unpredictable and is a function of the degree of interconnection of the water-bearing structures, as well as the differing depths of groundwater circulation.

\section{Uitenhage Springs}

Groundwater at the Uitenhage Springs (Fig. 1) flows from fractured TMG sandstone at the foot of the Grootwinterhoekberge, approximately $8 \mathrm{~km}$ north-northeast of Uitenhage in the west of the CRA. The cumulative artesian flow rate from nine eyes is $45 \mathrm{l} / \mathrm{s}$. The spring-flow rate has varied over time (Fig. 3), especially in the period from the early 1900 s to the 1960 s due mostly to overabstraction (Maclear and Woodford, 1995). The effect of this reduction in flow at the Uitenhage Springs (from $82 \ell / \mathrm{s}$ at the turn of the century, to $35 \mathrm{l} / \mathrm{s}$ in the late $1950 \mathrm{~s}$ ) resulted in the call for the declaration of a control area, since the Springs provided Uitenhage's main water supply at the time.

It is of interest to note that the major increase in boreholes drilled in the CRA during the period mentioned above did not increase the total yield of the unit, which remained relatively constant at $80 \ell / \mathrm{s}$, but rather increased the depth to the piezometric level (Fig. 1), thus changing pressure conditions from artesian to sub-artesian. If anything, the yield from the unit decreased slightly towards the end of the 1960s, as a result of increased leakage (through rusted borehole casings) of groundwater - under artesian pressure - into the confining overlying Cretaceous sediments.

\section{Swartkops Aquifer}

The Swartkops Aquifer (SA), shown in Fig. 1, comprises the area south of the Coega Fault and stretches from Groendal Dam in the west to below Port Elizabeth in the east. It has similar hydrogeological conditions to the Coega Ridge Aquifer, with the only major difference being the much greater depth to the TMG Aquifer in an easterly direction - a function of a thicker overburden of Cretaceous sediments. The SA is not linked hydraulically to the CRA and is semi-confined to unconfined on its southern boundary, with a piezometric level (and thus hydrostatic pressure) 100 to $120 \mathrm{~m}$ lower than that of the CRA.

The two hydrogeological units of the Swartkops Aquifer are discussed in more detail below.

\section{Kruisrivier Unit}

Drilling is generally successful to the west of the Kruisrivier Unit due to the relatively thin deposits of overlying Cretaceous sediments to be penetrated, before the TMG quartzites or basal sandstone layers of the Enon Formation are intersected.

As a result of observations by Marais (1965) that artesian pressure increases with increasing depth in the sandstone, it was deduced that there is no direct surface recharge to the artesian sandstone aquifer. Groundwater from the TMG aquifer (recharged by rainfall on the upper basin catchment) recharges the basal sandstone unit of the aquifers in the Kirkwood and Enon Formations by lateral and vertical pressure leakage to these formations from the bounding quartzitic sandstone unit.

This observation was supported by findings by Bush (1985), where groundwater quality analyses, carried out during pumping tests on exploration boreholes in the Kruisrivier Unit, showed that there was a decrease in salinity and an increase in acidity of the groundwater with increasing duration of the test. This is considered to be a function of progressively increasing groundwater contributions from the TMG quartzites and decrease in groundwater derived from the overlying mudstone.

High TDS concentrations in the Kruisrivier groundwater are a result of mixing of water derived from localised TMG sandstone outcrops and overlapping Cretaceous formations. Comparison of borehole hydrochemistry in this portion of the basin shows that boreholes abstracting groundwater from an aquifer of mixed provenance have a higher salinity than those from a quartzitic provenance.

The areas of Kruisrivier with low salinity groundwater, and consequently the areas of large-scale abstraction, correspond to areas obtaining their recharge directly from the Groot Winterhoekberge and Elands River Forest Reserve, rather than from seepage from the overlying clayey mudstones of the Uitenhage Group.

\section{Bethelsdorp Unit}

The Bethelsdorp Unit (Fig. 1) is located in the Swartkops Aquifer on the southern margin of the UAB and is bounded by the Cape Supergroup outcrop to the south, the Elands River Forest Reserve and Groot Winterhoekberge to the west, the shale-filled syncline to the north and Algoa Bay to the east. The major aquifer in the Bethelsdorp Unit is situated beneath the low-lying foot of the Bethelsdorp escarpment in fractured TMG quartzites, which are overlain by low-permeability, confining layers of the Bokkeveld Group sediments. Where the TMG Aquifer has not been penetrated by drilling, the Kirkwood Formation sandstone and the Enon Formation conglomerate are considered as the aquifer, with the Kirkwood Formation mudstone acting as the aquiclude.

The Bethelsdorp Unit is under-utilised compared with the Kruisrivier Unit. It is artesian to sub-artesian in places and has not been a focus of intensive study in the past. Boreholes of variable, moderate yields can be drilled with some degree of success. The boreholes drilled into this unit are relatively shallow (25 to $200 \mathrm{~m}$ ) with the highest yields being obtained from boreholes which first penetrate the confining Bokkeveld Group before intersecting TMG quartzites, thereby resulting in artesian conditions, with a general increase in yield with an increase in depth of TMG penetrated (Marais, 1965).

\section{Zwartkops Spa borehole}

A discussion of the Zwartkops Spa borehole - located in the Swartkops River Valley on the northern outskirts of Port Elizabeth - is relevant, since this famous borehole (location shown on Fig. 1) provides the only geohydrological information available for the deep discharge portion of the Swartkops Aquifer to the east of the basin.

The borehole was originally commissioned for oil exploration and drilling commenced in 1906 with the arrival of a drill crew from the oil fields of Poland. Drilling ceased in 1909 at a final depth of $1082 \mathrm{~m}$ below surface $(1075 \mathrm{~m}$ b.s.l. $)$ when hyperthermal $\left(54.5^{\circ} \mathrm{C}\right)$ 


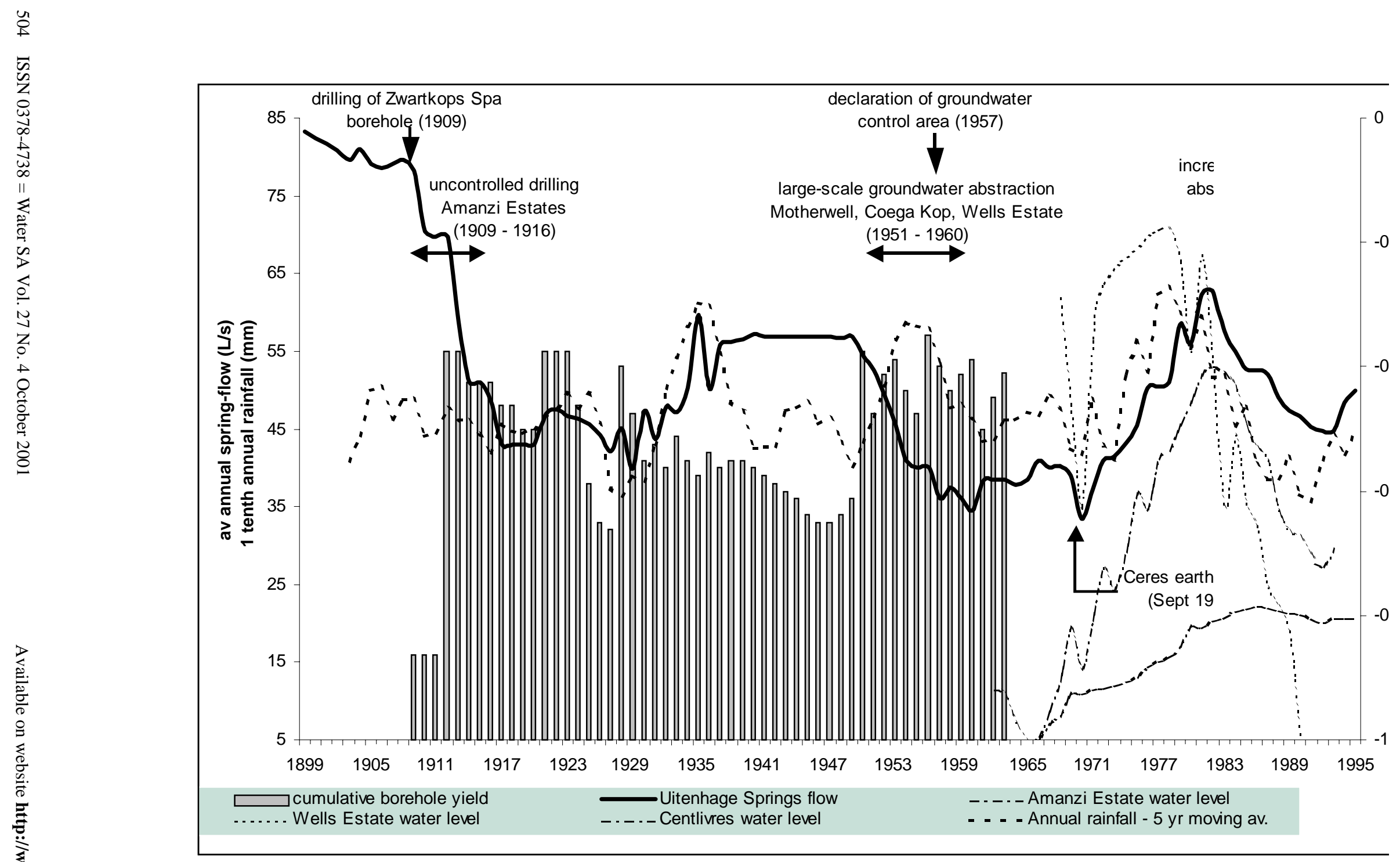

Figure 3

Flow variations at Uitenhage Springs (1899 to 1995) from Maclear (1996) 
artesian groundwater, flowing at a rate of $13 \ell / s$, was struck and the upward artesian pressure balanced the total weight of the drillstring, thereby making deepening of the borehole impossible.

The artesian flow of the Zwartkops Spa borehole is associated with a regional fault of similar character to that of the Coega Fault. Whilst the sandstone encountered at final depth was of uncertain geological origin, the hydrochemical nature of the groundwater indicates it to be a mixed sample of at least two major rock types: high Fe typical of TMG, but relatively high TDS $(560 \mathrm{mg} / \ell)$ indicative of the Bokkeveld Group.

The thermal properties of the TMG Aquifer host-rock in this part of the basin are a result of an increase in groundwater temperature with depth. This temperature increase is a function of the geothermal gradient of the host-rock, as well as residual heat from the structural deformation (specifically Mesozoic folding) which the Cape Supergroup underwent. Maclear (1996) calculated a depth of groundwater circulation for the Zwartkops Spa borehole at $1330 \mathrm{~m}$. Accordingly, the groundwater that fed the Spa borehole for 50 years originated from at least $250 \mathrm{~m}$ deeper than the depth of the thermal water-strike. This illustrates the structural complexity of the basin and the effect this has on the groundwater circulating conditions within the fractured TMG sandstone comprising this aquifer.

Due to the reported medicinal properties of the artesian groundwater, a hotel and health spa was built around the borehole, viz. the Zwartkops Spa. The claimed medicinal properties of the spa water can be attributed to the high Fe content and hypotonic nature of the groundwater, which was used consumptively, mainly in the treatment of anaemia. The Zwartkops Spa subsequently became one of the leading resorts of its type in the country. In 1965, however, the borehole became defunct as the steel casing rusted through due to the corrosive nature of the groundwater and groundwater subsequently leaked under artesian pressure at a rate of approximately $410000 \mathrm{~m}^{3} / \mathrm{a}(13 \mathrm{l} / \mathrm{s})$ into the Cretaceous sediments and overlying surficial alluvial deposits. In 1969 the borehole was eventually grout-sealed by the Drilling Division of the Department of Water Affairs and Forestry to prevent loss of groundwater from the Swartkops Aquifer and the Zwartkops Spa closed down.

\section{Discussions and recommendations}

The Uitenhage Artesian basin is the only extensive aquifer with free-flowing artesian conditions of its type in South Africa. Whilst it has been locally well studied, a need exists for basin-scale hydrogeological characterisation. The UAB is considered to be an ideal 'working model' of a fractured TMG Aquifer, since it contains all the variables found in similar Cape Fold-belt aquifers within a relatively small and well-defined area, such as artesian and sub-artesian conditions, cold to hyperthermal water and macro- to micro-scale fracturing. Such a study would produce a better understanding of TMG aquifers in South Africa to the benefit of groundwater users and advance the science of hydrogeology.

Since groundwater from this basin is an important supply of water for domestic and large-scale irrigation purposes, it is vital that a groundwater-resource awareness campaign is initiated and encouraged to ensure water conservation in the future. Since all groundwater resources only have a finite supply potential, demandbased abstraction from the basin should be planned and carried out on the advice of hydrogeological specialists, for the ultimate benefit of the groundwater users and the community who are dependent on this resource.

\section{References}

BUSH RA (1985) A Geohydrological Assessment of the Kruisrivier/ Bethelsdorp Systems - Uitenhage. Department of Water Affairs and Forestry Technical Report No Gh3458, Pretoria.

HEATON THE, TALMA AS and VOGEL JC (1986) Dissolved gas palaeo-temperatures and ${ }^{18} \mathrm{O}$ variations derived from ground water near Uitenhage, South Africa. Quaternary Res. 25 79-88.

HILL RS (1988) Quaternary faulting in the South-eastern Cape Province. S. Afr. J. Geol. 91 399-403.

JONES MQW (1992) Heat Flow in South Africa. S.A. Geol. Surv. Handbook 14, Govt. Printer, Pretoria.

MACLEAR LGA and WOODFORD AC (1995) Factors affecting springflow variation at Uitenhage Springs, Eastern Cape. Proc. Conf. Groundwater '95, Midrand.

MACLEAR LGA (1996) The Geohydrology of the Swartkops River Basin - Uitenhage Region, Eastern Cape. M.Sc. Dissertation. Univ. of Cape Town, Cape Town.

MARAIS JA (1965) Die Uitenhage Artesiese Kom. Department of Water Affairs and Forestry Technical Report No Gh 1476, Pretoria.

MARAIS JA and SAAYMAN CH (1965) 'n Geologiese-Geofisiese Ondersoek van die Uitenhage Artesiese Kom. Department of Water Affairs and Forestry Technical Report Gh 1516, Pretoria.

MOUNTAIN ED (1955) The Uitenhage Artesian basin. S.Afr. J. Sci.52 (3) 66-72.

TALMA AS, VOGEL JC and HEATON THE (1982) The geochemistry of the Uitenhage Artesian Aquifer - Carbonate solution in a closed system. IAEA 270 481-497.

TOERIEN DK and HILL RS (1989) The geology of the Port Elizabeth area. Explanation: Sheet 3324 (1 : 250 000). Geol. Surv., Pretoria.

VAN EEDEN OR (1952) Artesiese Water in die Omgewing van Uitenhage en Port Elizabeth. Department of Water Affairs and Forestry Technical Report No Gh 1171, Pretoria.

VENABLES AJ (1985) The Geology, Geohydrology and Hydrochemistry of the Uitenhage - Coega Artesian System. Department of Water Affairs and Forestry Technical Report No Gh 3437, Pretoria. 
